\title{
Financial Supervision and Staff Motivation as Institutional Variables for Predicting Agricultural Education Lecturers' Teaching Effectiveness in Nigeria Universities
}

\author{
Camilus Bassey Ben \\ Agricultural Education Unit, Department of Vocational Education, University of Calabar, Calabar, Nigeria
}

Email address:

camilusbassey@gmail.com

To cite this article:

Camilus Bassey Ben. Financial Supervision and Staff Motivation as Institutional Variables for Predicting Agricultural Education Lecturers' Teaching Effectiveness in Nigeria Universities. Education Journal. Vol. 4, No. 2, 2015, pp. 69-81. doi: 10.11648/j.edu.20150402.14

\begin{abstract}
This study was conducted to determine the extent to which institutional variables of financial supervision and staff motivation predict teaching effectiveness of Agricultural Education lecturers in Nigerian universities. Four null hypotheses were formulated on the basis of the independent variables of financial supervision, motivation, nature of teaching and the combined effect of the institutional variables respectively to guide the study. A 45-item questionnaire was structured to obtain data for the study. A survey research design was adopted for the study. A sample of 68 Agricultural Education lecturers was selected for the study using stratified sampling technique. The Pearson Product Movement Correlation and multiple regressions were the statistics used in data analysis. The results of the study revealed among others, that teaching effectiveness of Agricultural Education lecturers in Nigerian universities was significantly higher with respect to teachers' self-control, classroom design techniques, teaching of appropriate behaviour and student-teacher relationship. Also, the combined effect of institutional variables of financial management supervision, staff motivation, and student teacher - relationship were significant predictors of Agricultural Education lecturers' teaching effectiveness. It was recommended among others that the Nigerian Government and university administration should provide appropriate motivation and adequate funds for Agricultural Education programmes.
\end{abstract}

Keywords: Institutional Variables, Teaching Effectiveness, Motivation, Agricultural Education Lecturer, Agricultural Education, Financial Supervision, Nigerian Universities

\section{Introduction}

Education in general and university education in particular, is fundamental to the development of knowledge, economy and society in all nations. Therefore, education shall continue to be highly rated in national development plans as the most important instrument of change (FGN, 2000). According to Afe (2003), education, apart from being the most powerful instrument for social progress, is also the greatest power yet known to man for his improvement. The fundamental considerations upon which all business organizations are established are productivity, profitability and efficiency made possible through education. Owusu-Acheaw (2007) opined that an organization' primary aims of productivity and profitability are dependent upon education.

Agriculture is one of the core subjects in Nigeria education system. The important accorded it in the school curriculum reflects the recognition of the vital role it plays in contemporary society. The goal of teacher education in Nigeria includes, among others, the encouragement of the spirit of enquiry and creativity in teachers, and providing them with the intellectual and professional background that will be adequate for their assignments and also make them adaptable to changing situations (FGN, 2004). As entrenched in the policy, teacher education shall continue to take cognizance of changes in the methods and curriculum and teachers be regularly exposed to innovations in their profession. Agricultural Education is a formal academic programme of instruction systematically organized for inschool learners who are willing and ready to be prepared for a teaching career in agriculture. As an academic programme, Agricultural Education stresses in its content those professional skills required by a learner in professional education and vocational/ technical areas of agriculture. The vision is to produce globally competitive teachers who will contribute significantly to development through quality 
research and teaching. Agricultural Education Programme is hinged on the national philosophy of agriculture. It emphasizes self-reliance based on the production of professional teachers of agriculture endowed with balanced approach between principles and practice of agriculture for academic and skill development ends. The objectives of Agricultural education programme at the university level as highlighted by Ben $(2014: 1706)$ include:

1. To produce graduate teachers with the right attitude, knowledge, and professional competences in agriculture

2. To produce teachers who will be capable of motivating students to acquire interest in and attitude for agriculture

3. To develop in the prospective teachers of agriculture appropriate communicative skills for effective communication of agricultural information and skills to the students in the context of their environment.

4. To equip the prospective agricultural educators with adequate knowledge and ability to establish and manage model school farm effectively.

5. To provide a sound background to enhance further academic and professional progress of prospective agricultural educators.

6. To provide the high-level academic manpower in agricultural education needed at colleges of education, polytechnics, monotechnics, and universities

7. To provide a sound background in research skills and knowledge to enhance further academic and professional progress of prospective agricultural educators

By the policy stipulations, the professional training of teachers of agriculture is two-fold: pre-service and in-service trainings (FGN, 2004). To implement this, certain institutions are charged with the responsibility to provide the required pedagogical training. Universities in Nigeria are one of such institutions. The Nigeria universities are therefore, "train-thetrainer" institutions established to provide pedagogical and technical training to teachers to enable them carry out their professional duties. Graduate teachers from Nigeria Universities are assigned to teach in the nation's primary and secondary schools.

Faculties/Institutes of Education of universities in Nigeria train agricultural teachers by offering Bachelor of Science Education degree programme to candidates with Senior Secondary School Certificate and National Certificate in Education (NCE) qualifications. They also offer Master's and Doctorate degree programmes in Agricultural Education. For admission into the Bachelor of Science Education degree programme candidates with Senior Secondary School Certificate, the entry requirement is five credits, which must include Agricultural Science, the major teaching subject. In addition, prospective candidates are required to sit for an entrance examination, the Unified Matriculation Examinations (UTME). The pedagogical training prepares perspective teachers to participate effectively in the educational system and usually involves exposure to varied courses in the following areas:

i. General studies (Use of English, Introduction to
Computer, Entrepreneurship Development etc.)

ii. Core courses in education including Philosophy of Education, Sociology of Education, Psychology of Education, History of Education, Comparative Education, Schools Administration, classroom Management, and subject pedagogy

iii. Technical areas of agriculture: Crop Science, Animal Science, Soil Science, Agricultural Economics and Extension and Forestry and Wildlife Management

iv. Teaching Practice

v. Research Project

At the completion of the programme, trainees are awarded degrees based on their overall academic performance. Recently, they are also required to register with the Teachers Registration Council of Nigeria which is a body responsible for the licensing. At the fulfillment of these requirements, they are considered professional teachers of agriculture

Institutional variables have been a cause for concern in attainment of the objectives of Agricultural Education in Nigeria Universities (Osinem, 2008). It is observed that Nigerian universities generally, suffer inadequate funding. This results in inadequate tools and materials which adversely impact teaching and learning effectiveness. There is paucity of Agricultural Education lecturers. Also, the available ones are inadequately motivated leading to passive disposition in the dispatch of their teaching work role. There is a positive correlation between motivational factors and teaching effectiveness (Haruna, 2004). When properly used, staff motivation initiatives such as enriched physical working environment, adequate infrastructure, and attendance at workshops, seminars, and conferences could be a veritable tool for getting the most out of the teachers and at the same time enhance effective teaching.

Teachers hold the key that unlocks the door to modernization (National Universities Commission (NUC), 2006). No education system can rise above the quality of its teachers and that no national development can supersede the quality of her teacher. Teacher education is the foundation of quality education system. If Nigeria will achieve success in the production of well- informed Agricultural Education lecturers, sustained attention should be given to the indispensable elements of elements of institutional variables. According to Okure (2001), effective teaching of agriculture can only occur where there are effective teachers. Teachers need to be made effective by providing acceptable teaching method, effective class size and adequate staff-student ratio, adequate facilities that would ensure individualized teaching without increasing cost. Teachers are the doctors who strive to save life, the electrical engineers who produce illumination and power with which to see and operate, the farmers who produce food for the people and teachers train all the manpower needed for sustaining the above professions and upgrading the economic activities of the nation. It was against this backdrop that this study was conceived.

\subsection{Statement of the Problem}

When universities were initially established in Nigeria, 
Agricultural Education facilities were relatively adequate (Fafunwa, 2004). As students' enrolment increased with years, the facilities became grossly inadequate as there was no corresponding additional provision of resources to match with the demands. In this regard, Agricultural Education lecturers were faced with the problem of inadequacy and dilapidation of instructional resources. This inserted negative influence on their teaching, as they cannot deliver their lectures effectively and efficiently. This also results in students' failure and outcry from parents, employers and the society. The university administrators have the duty to procure, supervise and administer resources to enhance effective teaching and learning. The contemporary Nigeria Universities seems to suffer underfunding culminating into poor teaching materials and facilities. This ultimately results to apparent ineffectiveness in the job delivery. It was upon this backdrop that this study was conceived. This study therefore sought to establish a relationship between the institutional variables and Agricultural Education lecturers' teaching effectiveness. In other words, it tends to ask the question, do institutional variables of financial supervision and staff motivation influence Agricultural Education lecturers' teaching effectiveness in Nigerian universities?

\subsection{Purpose of the Study}

The purpose of this study was to ascertain the influence of institutional variables of financial supervision and motivation on Agricultural Education lecturers' teaching effectiveness in Nigeria Universities.

Specifically, the study sought to:

1. Establish the influence of institutional variable of financial supervision on Agricultural Education lecturers' teaching effectiveness in Nigeria Universities

2. Ascertain the influence of institutional variable of staff motivation on Agricultural Education lecturers' teaching effectiveness in Nigeria Universities.

3. Ascertain the status of Agricultural Education lecturers' teaching effectiveness

4. Determine whether institutional variables of financial supervision and staff motivation are significant predictors of Agricultural Education lecturers' teaching effectiveness in Nigeria Universities.

\subsection{Statement of Hypotheses}

The following hypotheses were formulated to guide the study:

1. There is no significant influence of institutional variable of financial supervision on Agricultural Education lecturers' teaching effectiveness

2. Institutional variable of staff motivation of staff motivation has no significant influence on teaching effective among Agricultural Education lecturers.

3. The teaching effectiveness by Agricultural Education lecturers is not significantly high

4. Institutional variable of financial resources and staff motivation are not significant predictors of Agricultural
Education lecturers' teaching effectiveness in in Nigeria

\subsection{Literature Review}

\subsubsection{Concepts of Institutional Variable and Teaching Effectiveness}

For any organization to achieve its goals there must be adequate resources at its disposal. The resources in the in Nigerian universities to be supervised are the human, material and money. The three are very important for optimization of Agricultural education programme. The human resource in this case is the lecturers; the material resources include the physical facilities, equipment and instructional materials. Fund is the money used in for recurrent expenses. There is a consensus among university administrators, educational planners and researchers that these resources are essential ingredients for effective teaching and learning outcome (Adeboyeji, 2004). In the same vein, Olaloko (2001) asserted that in Nigeria Universities supervision of available resources enhances and ensures effective realization of objective and worthwhile education services. The extent of supervision of personnel, physical facilities, curriculum and finance are major variables that are capable of determining the lecturers' teaching effectiveness in schools. In a study carried out by Okedara (2001) on administrators' supervisory management and teachers' productivity, the result revealed that teachers' productivity was dependent on administrator's supervisory and financial management. In the same vein, Akamkpa (2003) carried out a study on resource management and teachers' teaching effectiveness using teachers and students as respondents. The result showed that there was a significant influence of administrators' resource management effectiveness on teachers' over teaching effectiveness.

Effective supervision of available financial resources can lead to satisfaction which can enhance teachers' teaching effectiveness. This is because when the available financial resources are prudently utilized to provide needed facilities, the assurance is that the lecturers use them to facilitate their teaching. Where this is not the case, Agricultural Education teachers are forced to make choices which are unpleasant and often compromising. The teachers may be forced to resort to verbal explanations of practical-based lessons or may resort to giving assignments to students who will have to undertake an uphill task of searching for the required solution. Besides some teachers may skip or totally abandon some courses when faced with the challenges of paucity of essential instructional resources. This is an aberration on teaching effectiveness.

Teaching effectiveness connotes building strong relationship with students that cultivate the socially as well as intellectually and working collaboratively with other teachers and administrators, to create a culture of excellence and active encouragement. Sinha (2008) identifies four core components of teaching effectiveness. These are: self-control, classroom design techniques, teaching appropriate behavior, and students' teachers' relationship. He also pointed out key elements towards achieving high teaching effectiveness to 
include the following: prioritizing key tasks and remaining dedicated, focusing on team work, good leadership role, and good relations with students, good quality of workforce and a sound organizational culture

Motivation of lecturers is crucial and fundamental in achieving effectiveness and efficiency in the university system; the greater the level of motivation, the higher the quality of workers' contribution to the achievement of the organizational goal (Siggin, 2002). There is an extricable interplay among teaching effectiveness, satisfaction and productivity. Bryson (2000) identifies human motivation as the key to successful and effective supervision of an organization. This is because where the staff is actively motivated; there is usually a clearly noticed improvement.

Ekoh (2001) conducted a study on vice chancellors' administrative behavior and teaching effectiveness of lecturers in universities in south eastern states of Nigeria. The findings showed that high teaching effectiveness of lecturers was influenced by the diacritic administrative behavior of vice chancellors, age of lecturers, lecturer's workload, and teaching experience. According to Etor (2002), high morale among lecturers is a tangible indicator of high teaching effectiveness among them. Nsor (2002) carried out a study on the sources of low teaching effectiveness among teachers in the University of Ibadan, Nigeria. The result indicated that majority of subjects had experienced a high measure of low teaching effectiveness in the profession in areas that included salaries, poor human relations among staff, inadequate buildings and equipment, high teaching load, training inadequacy, lack of time for certain professional duties and low status of the profession in society. These are some of the problems our present day lecturers are facing in our tertiary institutions in Nigeria. The heads of departments as the closest super-ordinates of lecturers should do what they can to alleviate some of these problems to make for teaching effectiveness among lecturers.

Gregory (2002) pointed out that teaching effectiveness has some major components and factors that impact positively. These as highlighted by him include:

i. Increasing the staff degree of control over their work (that is providing the staff with the opportunity of setting their own goals)

ii. Providing the staff with the opportunity for participative decision making.

iii. Providing teaching equipment and material motivation.

iv. Increasing the professional competent of the teachers through in-service training, so that they may be better informed as decision makers.

v. Organizational communication.

vi. Delegation of powers (authority)

The university administrators that adhere to these may induce the lecturers under him or her to have a sense of satisfaction on the job performed.

Robbins (2004:132) in a related vein maintained that to enhance teaching effectiveness the university administrators should:

i. Supervise the skills and abilities of individual lectures indirectly to know how well they are doing, little challenges create boredom, too much challenge creates frustration and feeling of failure. Under condition of moderate challenge, most teachers will experience pressure.

ii. Provide personal comfort, comfortable physical environment, supervise modern facilities available, and with adequate materials and equipment to teach with.

iii. Agitate for the lecturers' pay and promote policies that they will perceive as being just. When pay is seen as fair based on job demands, individual skill level and community pay standards, high performance is likely to occur.

Teachers' teaching effectiveness is very important hence, Robbins (2004:139) concluded that:

i. There is clear evidence that low performed teachers skip work more often and more likely to resign.

ii. It has been demonstrated that teachers who are satisfied in the teaching effectiveness have better health and live longer.

iii. Satisfaction on the job performed carries over to the teacher's life outside the job.

An effective teacher helps students to learn, and builds strong relationship with students hence aids them socially as well as intellectually. Components like self-control strategies, classroom design techniques, teaching to appropriate behavior and student teacher relationship could be used to achieve teaching effectiveness.

\subsubsection{Financial Supervision Variable and Agricultural Education Lecturers' Teaching Effectiveness}

Financial supervision involves the prudent check, use, monitoring and control of funds in an organization. As pointed out by Ada (2004), it involves efficient and effective supervision of the inflow and outflow of funds with a view to breaking even to achieve objective and maximize profit. Accordingly, for any department in the university to consistently grow in its academic activities without seriously lacking in the provision of its basic instructional needs, the head of department should judiciously or prudently supervise the available. To this end, Amadi (2003) reiterated that funds in the university have to be used for the purpose it was meant for. It is true that the fund made available for the running of the department are usually negligible, even then it behooves on the head to supervise and manage such funds efficiently and effectively. Akube (2003), describes supervision as the efficient and effective use and check of human materials and financial resources. According to him effective means doing the right thing while efficient mean doing thing rightly. The head has to allocate the money on things that will bring growth to the department, because according to Isayaku (2003), if the available financial resources are not utilized as expected, the consequence may be as discrediting as if the funds were not available at all.

In a study conducted by Ekpiken (2002), on motivation and lecturers' perception of Head of Departments' administrative effectiveness it was found out that there was 
positive significant relationship between the financial and supervision behaviour of the Head of Departments' administrative effectiveness and lecturers' motivation and teaching effectiveness. He further pointed out that efficiency in the supervision of institutional finance depends largely on the level of investment (funding) of any institution.

Amadi (2003) conducted a study on teacher's perspective on resource supervision for effective instruction in Nigerian Universities. The findings revealed that though the funds available for instructional supply are limited, but the little available funds often mismanaged because of lack of supervision. It was therefore emphasized that school funds should be used for the purpose of purchasing instructional aids, agricultural equipment and resources room for effective instruction by lecturers. This would normally lecturers' work effective and thus enhance their teaching effectiveness. In the same vein Akpama (2003) conducted a study on university administrators' resource management and teachers' teaching effectiveness in Cross River State. The result revealed that lecturers' perception of their administrators' financial management effectiveness significantly influenced their teaching effectiveness.

Abi (2007) conducted a study on the influence of finance on administrative efficiency of universities in south Eastern States of Nigeria, using lecturers from five selected universities. The findings showed that inadequacy and delay in the released of funds to vice chancellors seriously affected the administration of universities in the geographical zone. He recommended that budgeted finance should be released to vice chancellors to enhance the effective running of their institutions. He revealed that the imprest system of funding in the university is faulty with a fixed meager amount of money for all departments as well as irregular or non-release of such funds to heads of department to enable them provide for the instructional needs of lecturers to enhance their efficiency and teaching effectiveness.

According to Lodie (2002), the need to supervise available financial resources effectively should be viewed as very critical, most especially since universities are restricted in their ability to generate further resources. Ezeocha (2005) pointed out that only a financially viable university can function well, and that it is quite an uphill task to operate any system without adequate finance because this can result in frustration on the job. It is a general complaint that funds to run the universities and departments are always not enough; therefore the heads of departments who want their departments to move forward in terms of having the needed instructional materials and meeting other educational needs should source for funds. Denga (2003) stated that many tertiary institutions have been forced to adopt cost mitigating strategies such as establishing endowment funds, persuading wealthy individuals and private sectors to donate funds to institutional developmental strides. In the same vein, departmental heads can source for funds for their departments by contacting their alumni, starting small scale business, printing departmental hand book, running a journal etc. This can boost the financial stand of the department.
Every head knows that fund in the department are meant for the running of department, via provision of agricultural materials and supporting lecturers to improve teaching materials that are in short supply, because according to Eziegbe (2003), lack of financial support from the administrators to encourage the teachers provide needed materials is a serious constraint which can result in poor teaching effectiveness.

Offiong (2004) studied the correlates of administrative efficiency among secondary school principals in Cross River State, Nigeria and found that the level of availability of funds has significant influence on the principals' administrative efficiency. This means that if the funds are available the administrators can attend to their numerous institutional needs expressed by lecturers as a strategy so as to sustain their teaching effectiveness. In the same vein, the study carried out by Nyong (2001) on factors that influence administrative effectiveness of principals in Akwa Ibom State, Nigeria using teachers and students from secondary schools found out that there was significant relationship between level of financial and administrative effectiveness of principals. From the foregoing, it can be deduced that the supervision of an administrator depend to a large extent on the availability of adequate funds at his/her disposal. It is however expected that he /she should be effective in the supervision of such funds. Ezeocha (2005) further pointed out that the school administrator who administers school or department imprest account should see that records are carefully kept of all items of expenditure, and should also ensure that a good accounting system is in place. Okorie (2001),lamented that so much attention in the professional literature and even at conferences has been given to the administrator's role concerning instruction, but very few articles seems to have been written about financial supervision strategy. She stressed that this calls for concern as it is a common knowledge that administrators in our schools tend to be transferred or lose their jobs due to financial misappropriation. Accordingly, Okeke (2005), cited in Okorie (2001), advised that administrators should have a fair knowledge of accounting so as to be able to administer accounting and auditing functions. This is very important so that he or she may be able to defend himself /herself in cases of accusations of poor financial supervision.

However, it is a common practice for administrators to misappropriate funds entrusted to them. In this regard, Aguokoagbuo (2003:252) has recommended that:

i). Money meant for the purchase of facilities and equipment and other teaching materials should be judiciously used for the purpose.

ii). Administrators or persons who embezzled institutional funds should be made to pay back.

iii). Appointment of an administrator should be based on merit.

This means that only lecturers of proven integrity and character should be appointed heads of department in Nigeria universities irrespective of their seniority in ranking. This is because they will put the interest of the department first 
before their personal interest. Furthermore, in a study conducted by Akpan (2002) on financial management using teachers as respondents, the findings showed a significant relationship between the amount of imprest received and the administrators supervision on the utilization of such imprest in the provision of facilities and equipment for use by teachers as well as to motivate them.

Effiong (2009) investigated the relationship between finance and supervision of secondary schools in Itu Local Government Area of Akwa Ibom State, Nigeria. He found out that the level of administrators, satisfactory supervision was specifically influenced by the sum total of the revenue made available for his/her use. Further emphasizing the importance for adequate funding in the successful implementation of instructional programmes, as inadequate funding and poor supervision has been identified as one of the factors militating against poor teaching effectiveness. Prudence in the supervision and management of funds by administrators should be among the rank and file in the university setting.

\subsubsection{Staff Motivation Variable and Agricultural Education Lecturers' Teaching Effectiveness}

Ndagana (2007) opines that teaching effectiveness and motivation are two side of the same coin. He contends that lecturers teaching effectiveness and motivation are twin inseparable concepts. A well performed worker is a motivated worker and vice versa. When a worker performed well in his work he is contented with his work. A well performed worker is a happy worker. A well performed worker looks at him as the best that could happen to his organization. He also looks at his organization and his assignment as the possible best anywhere in the world. When he compares his salary and all other accruable benefits with those of other lecturers in the same institution or any other institution under prevailing socio-economic, circumstances a motivated worker rates himself very highly. He feels far better than his counterparts.

Ali and Ahmed (2009) report in their study that there is a statistically significant relationship between reward and recognition and motivation and performance respectively and that if rewards or recognition offered to employees were to be altered, and then there would be a corresponding change in work motivation and performance. Similarly, Kaya (2005) posited that teaching effectiveness plays a great role in the type and quality of service that lecturers render. Fitzgerald (2005) affirmed that appropriate compensation system would affect the performance and the productivity of the employment. Storey and Sission (1999) aver that staff training and development would not only enhance skill of the worker, but could also make them realize how they are valued by the organization. Henman (2007) admitted that if properly used, staff motivation could become a vital tool to get the best out of the workers. He emphasizes further the impact of using different strategies and demeanour such as: speaking positive words to applaud a good job, exercising restrain, patience and understanding on staff as morals booster with a view of getting the best out of them.
In a formal organization, staffs are recruited principally for the performance of tasks that would result in the attainment of the organizational goals. According to Gregory (2002), motivation is therefore closely interwoven with behavior and there are a variety of factors that affect it. These factors are the needs of the individuals and the attitude of supervisors (administrators) towards them. The pioneering work of Herzberg, Mausner and Synderman carried out in 1959 among factory workers revealed the following factors which if considered motivates people to work: (i)Intrinsic motivators which are growth oriented factors (ii) Extrinsic (maintenance of hygiene) factors which are peripherally related to the job. Herzberg factors, which are- sense of achievement, recognition for job well done, work itself, responsibility, advancement (promotion) and growth i.e opportunity for professional training are capable of producing good teaching effectiveness since there are related to the job content. On the other hand maintenance of hygiene factors which are institutional (company) policy and administration, supervision, working conditions, interpersonal relations (with peers, and superiors), salary and job security, cannot be themselves promote job because they are associated with the work context or work setting

Motivation may also be recognized as being positive or negative, for example, poor salary paid regularly as at when due could become a positive motivator than good salary that is paid irregularly. Denga (2006) defined motivation as the inner force which ignites, propels, spurs, energizes, direct and sustain behavior towards goal attainment. George and Jones (2009) viewed motivation as important because it explains why workers behave the way they do. To them work motivation involves the psychological forces within a person that determines the direction of a person's behavior in an organization, a person's level of persistence in the face of obstacles. Etuk (2001) defined motivation as the willingness of propensity of an individual to act in a certain way and that the willingness or propensity depends on a person's motives and abilities.

John (2006) conducted a research study on the applicability of Maslow's Need Theory in secondary schools administration in Cross River State, Nigeria and discovered that teachers were not effective while being utilized at work because their needs were not met. He concluded that teachers should be adequately motivated so as to awaken their interest and attain high teaching effectiveness. In tertiary institutions, lecturers are assigned teaching and other functional duties by their various heads of departments referred to as administrators in this study. Moreover, the college provost, rectors, dean of faculties and even vice chancellors also assign some special duties to lecturer of proven integrity in various aspects of the institutional administration. These are aspects of stage utilization. But to enhance their commitments, and dedication to such duties, the staff concerned should be motivated to create in them a sense of fulfillment and satisfaction.

Motivation as a supervisory strategy and teaching effectiveness should be of great concern to the administrators 
of Nigeria universities. Sherman and Denga (2006) asserted that employees' performance is an important dimension of the motivational process which reflects the degree to which the individual perceives that the needs are being met. Edem (2002) suggested that administrators should adopt a motivational strategy such as making the teacher to participate in major policy-making decisions, assisting them to improve their teaching skills (through staff training) being attentive to their materials and social problems, and by procuring for them sufficient teaching equipment and facilities. In a study conducted by Frase, Hetzel and Grant (2002) on promoting instructional excellence through a teacher reward system; Herzberg theory applied, concluded that staff recognition through conference sponsorship was highly cherished by teachers. Moreover teachers believe that professionalism and value to their institutions were greatly enhanced as a result of conference attendance.

In another study concluded by Tientjen and Myers (2008) on motivation and teaching effectiveness, it was concluded that although aspects of one's personal life as well as non-job factors at work influence the performance of the staff, it is the work itself which brings fulfillment. To this end, the study concludes that the tasks of staff should be altered in such a way that the fulfillment gained from doing the job is expected daily. This is why Herzberg's motivation Hygiene Theory of 1968 suggested that jobs should be enriched, enlarged and related to one's abilities to include the motivating factors in order to utilized workers effectively and thus increase their teaching effectiveness. In Nigeria universities, this may be adopted in the form of reassigning courses which have been taught by a particular lecturer for over ten to fifteen years, while assigning that lecturer another set of courses that can promote further research and professionalism in his/her field of study.

In a study conducted by Engelking (2006) on teachers' high and low performance, the findings which were based on Herzberg's (1968) showed that recognition and achievement were significantly highest as performed while communication with administrators was ranged highest as low performed. This shows that administrators in need to do more to maintain high degree of staff performance in their mode of communication, both written and spoken. It is sometimes disheartening for lecturers to hear official release or statements from students while the information would only be heard by the staff through radio or television broadcasts. These are aspects of dissatisfaction which can cause low teaching effectiveness and should be corrected in the system.

In a study on Maslow's hierarchy of needs and employee' motivation in Nigeria motivation, conducted by Emosairu (2002), it was concluded that effective motivation of university teachers was contingent upon the integration of the individual needs of individual lecturers into the traditional goals of the college which initially attracted them to the system. This is evidence in the issue of outcry of university lecturers against any form of government interference with college autonomy that would naturally breed low performance among lecturers. Thus an administrator who indulges in undue infringement on the rights and freedom (autonomy) of the lecturers through high handedness and lacking in the spirit of comradeship has failed to motivate them for higher performance. Hence, Emosairue (2002) in a study on administrative factors and supervision of higher education in Abia State, Nigeria concluded by tasking educational administrators to create conditions in which the needs of the faculty or departments are given priority attention by building into peoples' (lecturers) jobs, specific conditions and opportunities for personal achievements recognition and challenging works that would enhance teaching effectiveness.

The influence of motivation on university lecturers' work role disposition is enormous. A motivated lecturer, under normal circumstances would be a happy, joyous and at the same time highly effective in job disposition. This is because when the lecturer is happy he will under normal circumstances be willing to give the best to his students. In other words, a motivated lecturer does not need to be coerced to do his normal duties, but will rather be willing to discharge it joyfully, optimally and efficiently. A motivated lecturer would be willing to do everything possible to optimize his performance since this has direct bearing on the total university performance.

\section{Methodology}

The Ex-post facto research design was used for this study. This research was conducted in the six states that constitute the south-south geo-political zone of Nigeria namely, Akwa Ibom, Bayelsa, Cross River, Delta, Edo and Rivers State. The population of the study was 68 Agricultural Education lecturers. This comprised all the lecturers in universities that offer Agricultural Education programme in South-South geo political zone. The total population of the Agricultural Education lecturers from both federal and state universities in south-south geo-political zone of Nigeria was small therefore no sampling was carried out. The entire population of Agricultural Education lecturers was involved in the study. A structured questionnaire was used as instrument for collecting data for the study. The items in the study instruments were developed personally by the researcher. The items were developed on the basis of the major independent and dependent variables that directed the study. The instrument consisted of three sections; A, B, and C. Section A was developed to elicit information on respondents' demography such as their school location, sex, age bracket, qualification and years of teaching experience. The questionnaire was vetted by the project supervisors and useful suggestions were offered so as to ascertain its face validity. It was also validated by a Test and Measurement expert in the Faculty of Education, University of Calabar, Nigeria.

To determine the reliability of the instrument, a trial testing was done using 20 lecturers drawn from universities from the South East geopolitical zone of Nigeria who were not part of the study. Test retest method of reliability was used to 
determine the reliability estimate of the instrument. Here the researcher gave the same group of respondents the questionnaire to complete and after two weeks interval, they were again given the same questionnaire to complete. The scores for the set of administration were correlated. This method yielded reliability coefficients as follows: Institutional variables: of financial supervision strategy (0.78) and motivation (0.84); Teaching effectiveness: self-control (0.75), classroom design techniques $(0.72)$, teaching of appropriate behavior (0.81), student's lecturer relationship (0.83). These indicated that the instrument was reliable.

The research instrument was administered personally by the researcher with the help of a research assistant who was trained specifically for this purpose. The hypotheses postulated for this study were tested at 0.05 significance level using the following statistical tools: Pearson Product Moment Correlation Coefficient (r), Independent t-test, Population ttest and Multiple Linear Regressions. The decision rule that guided the result interpretations was that the null hypothesis was accepted if the calculated t- value was less than or equal to the critical t- value and vice versa

\section{Presentation of Results}

\subsection{Hypothesis One}

There is no significant influence of the institutional variable of financial supervision strategy on the teaching effectiveness of Agricultural Education lecturers in Nigeria universities

The dependent variable in this hypothesis was teaching effectiveness of Agricultural Education lecturers (as categorized into four sub-scales) while the independent variable was financial resource supervision. To test this hypothesis, the Pearson Product Moment Correlation Coefficient (r) analysis was used. The results of the analysis as tested through all the four sub-scales of the dependent variable (self-control, classroom design techniques, teaching of appropriate behaviour, and Students'- lecturers' relationship) are presented in Table 1

Table 1. Pearson Product moment correlation analysis of influence of financial supervision on agricultural lecturers' effectiveness in Nigeria universities

\begin{tabular}{lllll}
\hline Variable & $\sum \mathbf{X} \sum \mathbf{Y}$ & $\sum \mathbf{X}^{2} \sum \mathbf{Y}^{\mathbf{2}}$ & $\sum \mathbf{X Y}$ & r-cal. \\
\hline Self-control & 100.20 & 404 & 592.10 & $0.174 *$ \\
Classroom design techniques & 705.2 & 846.09 & 124.40 & 0.152 \\
Teaching of appropriate behavior & 1067.0 & 108.73 & 159.90 & 0.152 \\
Students'- lecturers' relationship & 119.0 & 330.14 & 486.0 & $0.204 *$ \\
Teaching effectiveness & 869.0 & 515.20 & & $0.243 *$ \\
\hline
\end{tabular}

*Significant at $\mathrm{P}<.05, \mathrm{df}=67, \mathrm{Crt}-\mathrm{r}=0.195$ (2 tailed)

Data in Table 1 indicated that all the calculated r-values of $0.174,0.224,0.204$ and 0.243 were found to be greater than the critical r-value of 0.195 needed for significance at 0.05 alpha levels with degrees of freedom. With these results the null hypothesis was rejected for all sub-scales of the dependent variable. This meant that teaching effectiveness of Agricultural Education lecturers was significantly influenced by the institutional variable of financial resources supervision strategy in Nigeria universities. Further indications were that the calculated r-values showed that they were all positive. This meant that the higher the rate of institution supervision of the financial resource variable, the more effective lecturers of agricultural education become in in their teaching particularly in terms of self-control, classroom design techniques, teaching of appropriate behaviour and Students'lecturers' relationship.
Institutional variable of staff motivation of staff motivation has no significant influence on teaching effectiveness of Agricultural Education lecturers in Nigeria universities.

The independent variable in this hypothesis was staff motivation strategy (uncategorized), while the dependent variable was lecturers' teaching effectiveness (categorized into self-control, classroom design techniques, teaching to appropriate behaviour, and student-teacher relationship).

The respondents were categorized into two groups; motivated and unmotivated. To test this hypothesis data was summarized into mean (X) and standard deviation (SD), as well as according to each sub-variables of the dependent variable. The summarized data was then subjected to statistical analysis, using the independent t-test analysis procedures. The results of the analysis are presented in Table 2.

\subsection{Hypothesis Two}

Table 2. T-test analysis of influence of institutional variable of motivation on Agricultural Education lecturers'teaching effectiveness in Nigerian universities.

\begin{tabular}{|c|c|c|c|c|c|}
\hline Variable & Motivation & $\mathbf{N}$ & $\mathbf{X}$ & SD & t-cal. \\
\hline \multirow{3}{*}{ Self-control } & Motivated & 28 & 14.31 & 3.08 & \multirow{3}{*}{$3.888^{*}$} \\
\hline & Not motivated & 40 & 11.42 & 4.23 & \\
\hline & Total & 68 & 12.865 & 3.655 & \\
\hline \multirow{3}{*}{ Classroom design techniques } & Motivated & 32 & 12.594 & 2.331 & \multirow{3}{*}{$1.983^{*}$} \\
\hline & Not motivated & 36 & 11.142 & 3.659 & \\
\hline & Total & 68 & 11.868 & 2.995 & \\
\hline Teaching of appropriate behaviour & Motivated & 48 & 17.377 & 2.331 & $3.228^{*}$ \\
\hline
\end{tabular}




\begin{tabular}{llllll}
\hline Variable & Motivation & N & X & SD & t-cal. \\
\hline & Not motivated & 20 & 14.526 & 3.659 & \\
& Total & 68 & 15.952 & 2.995 \\
& Motivated & 22 & 16.988 & 2.531 & \multirow{2}{*}{$5.573^{*}$} \\
& Not motivated & 46 & 13.464 & 3.046 & 2.789 \\
& Total & 68 & 15.226 & 26 & \\
\hline
\end{tabular}

$\mathrm{N}=68, *$ Significant at $\mathrm{P}<.05, \mathrm{df}=66$, Critical $-\mathrm{r}=0.195$ (2 tailed $)$

From Table 2, the calculated t-values of $3.888,3.288^{*}$ and $5.573 *$ were all higher than the tabulated t-values, while the calculated t-value of 1.983 was found to be lower than the tabulated t-value of 1.968 needed for significance at 0.05 alpha level with 67 degrees of freedom. With these results, the null hypothesis was rejected for the three sub-scales of self-control, teaching of appropriate behaviour and Students'- lecturers' relationship, but retained for the subscale of classroom design technique. This means that there is significant difference in the teaching effectiveness of Agricultural Education teachers who are institutionally motivated and others who are not motivated, only with respected to self-control (mean $=12.856$; teaching appropriate behavior (mean $=15.952)$ and student - teacher relationship (mean $=15.226$ ) but not in term of classroom design techniques $($ mean $=11.868)$, in Nigeria universities. This means that there is no significant difference in the teaching effectiveness of agricultural Education lecturers between those who are motivated and others who are not motivated in terms of classroom design techniques.

\subsection{Hypothesis Three}

The extent of teaching effectiveness of Agricultural Education lecturers in Nigeria universities is not significantly high

The independent and dependent variables in this hypothesis are the same i. e. the hypothesis is single variable (or one-tailed) with the main variable as teaching effectiveness as categorized into the four sub-scales of selfcontrol, classroom design technique, teaching appropriate technique, and students-lecturers' relationship. To test this hypothesis, population t-test statistical analysis procedures were applied. The results of the analyses are presented on Table 3 .

Table 3. Population t-test analysis of the extent of Agricultural Education lecturers'teaching effectiveness in Nigeria universities

\begin{tabular}{llll}
\hline Variable & $\boldsymbol{\mu}$ & SD & Cal.t value \\
\hline Hypothesized mean & 12.50 & & \\
Self-control & 13.816 & 2.433 & $7.019^{*}$ \\
Classroom design techniques & 14.812 & 3.214 & $10.713^{*}$ \\
Teaching of appropriate behavior & 15.464 & 2.816 & .000 \\
Students'- lecturers' relationship & 17.377 & 2.2499 & .000 \\
\hline
\end{tabular}

$\mathrm{N}=68, *$ Significant for all groups at $\mathrm{P}<.05, \mathrm{df}=66$, critical value $\mathrm{t}=1.968(1$ tailed $)$

In Table 3 , the calculated population t-values of 7.019 , $10.713,14.672$ and 27.007 were all found to be greater than the tabulated t-value of 1.968 , needed for significance at 0.05 alpha level, with 67 degrees of freedom. With these results, the null hypothesis was rejected. This meant that the teaching effectiveness of Agricultural Education lecturers in Nigeria universities was significantly high in terms of teachers' selfcontrol, (13.816), classroom design technique 14.812), teaching of appropriate behaviour (15.464) and Students'lecturers' relationship (17.377). The higher the mean score, the more effective the respondents (Agricultural Education lecturers).By this analogy, the respondents in this study perceived students'- lecturers' relationship as the best based on the high mean scores. This was followed closely by teaching of appropriate behaviour (with mean $=15.464$ ), classroom design technique with mean $=14.812$ and teachers' self-control with the least mean score of 13.816.

\subsection{Hypothesis 4}

Institutional variable of financial resources supervision and lecturers' motivation are not significant predictors of Agricultural Education lecturers' teaching effectiveness in Nigeria Universities

In this hypothesis, the dependent or criterion variable was teaching effectiveness while the independent or predictive variables were the five indicators of institutional variables financial resources supervision, and lecturers' motivation. To test this hypothesis, data were summarized into their sums $\left(\sum X, \sum Y\right)$, squares $\left(X^{2}, Y^{2}\right)$, sum of squares $\left(\sum X^{2}, \sum Y^{2}\right)$ and sum of products $\left(\sum X Y\right)$ etc. The summarized data were subjected to analyses using the Linear Multiple Regression Statistics. The results of the analyses are presented in Tables 4,5 , and 6 . 
Table 4. Summary of analysis of Multiple Linear Regression of institutional variables of financial resources supervision and lecturers' motivation on agricultural education lecturers' teaching effective in Nigeria universities.

\begin{tabular}{|c|c|c|c|c|c|c|c|c|c|}
\hline Enter model & $\mathbf{R}$ & $\mathbf{R}^{2}$ & $\begin{array}{l}\text { Adjusted } \\
\text { R-square }\end{array}$ & Std. Error of Estimate & Change-states & F-change & df & $d f^{2}$ & P-cal \\
\hline \multirow{6}{*}{$\begin{array}{l}1 \\
\text { Enter model } \\
2\end{array}$} & 0.63 & 0.68 & 0.363 & 4.06995 & 0.400 & 10.688 & 4 & 64 & .000 \\
\hline & & Sum of square & df & Mean square & F- Cal. & p-value & & & \\
\hline & Regression & 78.162 & 6 & 177.041 & & & & & \\
\hline & & & & & $10.688^{*}$ & .000 & & & \\
\hline & Residual & 1060.127 & 62 & 16.564 & & & & & \\
\hline & Total & 1768.289 & 68 & & & & & & \\
\hline
\end{tabular}

a) Predictors constant: financial resources and lecturers' motivation

(b) Dependent Variable $=$ Teaching effectiveness:

Result: significant at $\mathrm{P}<.05, \mathrm{df}=6$ and 62

From the result in Table 4, it could be observed that when all the predictor variables were combined together using the "Enter" model, a significant R-value of 0.633 was recorded, with a $\mathrm{R}^{2}$ - value of 0.620 . This meant that all the major institutional variables put together could account for about 62.0 percent of the total weights predicting the teaching effectiveness of Agricultural Education lecturers in Nigerian universities. The remaining 38.8 percent of the weight could be attributed to inexplicable values, I.e. factors other than those used in this study.

A further look at Table 4 (Model 2 summary) values a calculated ANOVA fishers $(\mathrm{F})$ value of $10.688^{*}$. This value was found to be higher than the critical F-value of 3.002, needed for significance at 0.05 alpha levels with 5 and 63 degrees of freedom. With this result the null hypothesis was rejected - thus implying that the combined effects of institutional variables of financial supervision, lecturers' motivation and students'-lecturers' relationship are significant predictors of Agricultural Education lecturers' teaching effectiveness. For a clearer understanding of the interactive effects of the individual predictive variables, Table 5 presented for detail.

Table 5. Model summary of Pearson Product inter-correlations among teaching effectiveness of Agricultural Education lecturers in Nigeria Universities.

\begin{tabular}{lllll}
\hline $\begin{array}{l}\text { Pearson Correlation }(\mathbf{r}) \\
\text { Constant }=\mathbf{A}\end{array}$ & $\begin{array}{l}\text { Teaching effectiveness } \\
(\mathbf{Y})\end{array}$ & $\begin{array}{l}\text { Human resource } \\
\text { supervision }\left(\mathbf{X}_{\mathbf{3}}\right)\end{array}$ & $\begin{array}{l}\text { Facilities supervision } \\
\left(\mathbf{X}_{\mathbf{4}}\right)\end{array}$ & $\begin{array}{l}\text { Students'-lecturers' relationship } \\
\left(\mathbf{X}_{\mathbf{5}}\right)\end{array}$ \\
\hline Teaching effectiveness & $(\mathrm{Y})$ & .108 & .026 & $.219^{*}$ \\
Financial & $\left(\mathrm{X}_{3}\right)$ & .50 & 1.000 & $.661^{*}$ \\
resource supervision & $\left(\mathrm{X}_{4}\right)$ & $.272^{*}$ & $.855^{*}$ & 1.000 \\
$\left.\begin{array}{l}\text { Lecturers' motivation } \\
\begin{array}{l}\text { Students'-lecturers' } \\
\text { relationship }\end{array}\end{array} \mathrm{X}_{5}\right)$ & $.302^{*}$ & $.281^{*}$ & $.626^{*}$ \\
\hline
\end{tabular}

$\mathrm{N}=68 *$ Results significant at $\mathrm{P}=.05, \mathrm{df}=66$, critical $-\mathrm{r}=0.195$ (2 tailed)

Results in Table 5 indicated that all the correlation coefficient results revealed that all the variables entered in the model have proven to contribute effectively in the prediction of the dependents variable-teaching effectiveness of Agricultural Education lecturers in Nigeria universities.

To further buttress the above explanation, Table 6 showing the Beta $(\beta)$ (weights, or regression coefficient, for each predicting variable, is thus presented.

Table 6. Model summary of $\beta$-co-efficient for the predicting factors.

\begin{tabular}{|c|c|c|c|c|c|c|c|c|c|}
\hline \multirow[t]{2}{*}{ Model } & & \multicolumn{2}{|c|}{$\begin{array}{l}\text { Unstandardized } \\
\text { coefficients }\end{array}$} & \multicolumn{2}{|c|}{$\begin{array}{l}\text { Standardized } \\
\text { coefficients }\end{array}$} & \multirow[t]{2}{*}{ Significance } & \multicolumn{3}{|c|}{ Correlations } \\
\hline & & $\beta$ & Std. Error & $\beta$ & $\mathrm{t}$-value & & Zero code & Part & Partial \\
\hline 2 & Constant & 13.694 & 4.395 & - & 3.116 & .003 & - & - & - \\
\hline$X_{I}$ & Financial resource supervision & .794 & .180 & .524 & $4.402 *$ & .000 & 574 & .482 & .426 \\
\hline $\mathrm{X}_{2}$ & Lecturers' motivation & 2.43 & .154 & .177 & 1.576 & .120 & .412 & .193 & .153 \\
\hline
\end{tabular}

*Significant at $\mathrm{P}, .05$, critical $-\mathrm{t}=1.968$ (2 tailed).

Constant: Dependent Variable: Teaching effectiveness: Predictors: $\mathrm{X}_{1}, \mathrm{X}_{2}$

From Table 6, it could be observed that the regression constant derived from the analysis was 13.694 with regression weights (or $\beta$-variables) of $-2.167,0.523,4.402$ and 1.576 respectively. That is, the calculated t-values of 4.402 for financial supervision were found to be greater than the critical t-value of 1.968 , while the t-value of 1.576 for lecturers' motivation were found to be lower than the critical t-value of 1.968 , needed for significance at 0.05 alpha level with 58 degrees of freedom. With these results, the null hypothesis was rejected (especially with respect to Financial resources supervision, but retained for lecturers' motivation. The implication of this result was that while financial supervision highly predicted the dependent variable $\left(\mathrm{X}_{\mathrm{I}}=\right.$ 2.167, $\mathrm{X}_{3}=4.402$ ) lecturers' supervision predicted the dependent variable lowly $\left(X_{2}=0.502, X_{4}=1.576\right)$. From the analysis, it could be inferred that Agricultural Education lecturers' teaching effectiveness is predicted mainly by a regression constant factor or weight 13.694; this is followed 
by financial resources supervision, then by weight of lecturers' motivation respectively.

\section{Discussion of Findings}

\subsection{Financial Supervision and Agricultural Education Lecturers' Teaching Effectiveness}

The findings in this aspect of the study revealed that there was significant influence of the institutional variable of financial management supervision on teaching effectiveness of Agricultural Education lecturers in Nigeria universities, mainly with regard to self-control, classroom design techniques, teaching of appropriate behavior and students teacher relationship. But no significant effect of financial supervision strategy exists with respect oto self-control. For the significant category of teaching effectiveness, the results showed that the more the financial management supervision, the higher the teaching effectiveness of the Agricultural Education lecturers.

These findings were in consonant with Ada (2004) who in his study pointed out that that for any department in tertiary institution to consistently grow and advance such department must endeavour to overcome the issue of "serious lack" in the provision of such basic necessities as human and physical infrastructures and amenities. Furthermore, the departmental head should judiciously or prudently supervise its financial resources however small it may be at his/her disposal. It is to this end, and in line with the findings of this study that Amadi (2003 reiterated that school funds has to used strictly for the purpose it was meant for.

Corroborating the above facts, Ekpiken (2002) pointed out that efficiency in the supervision of institutional finance depends on extent of availability. Financial supervision is a sine quo non for improving to a large extent teaching effectiveness of Agricultural Education lecturers in Nigeria Universities. This is because as has been asserted by professionals like Amadi (2003), Ekpiken (2002), Okorie (2001) and Karmel (2001) among various others, effective financial supervision enables lecturers to develop themselves through seminars, conference and professional workshops attendance and participation.

Effective financial supervision also enables the principals and head of departments to procure relevant Agricultural Education equipment and facilities necessary for the smooth running of the department as well as the actual participatory behavior of both lecturer and students in Agricultural Education activities to be enhanced and advanced. In line with the above assertions, Akpama (2003) whose findings also agreed fervently well with the findings of this study revealed that teachers' teaching effectiveness has always been found to correlate effectively well with the provision and availability of funds as a quintessential factor.

\subsection{Motivation and Agricultural Education Lecturers' Teaching Effectiveness}

The findings in this aspect of the study revealed the fact that there was significant difference in the teaching effectiveness of agricultural education teachers who were institutionally motivated and others who perceive themselves as not institutionally motivated in their teaching especially with respect to self-control, teaching of appropriate behavior, and students-teacher relationship. On the other hand agricultural education lecturers' teaching effectiveness was not significantly different among lecturers who were institutionally motivated with respect to classroom design techniques.

These findings were in agreement with Ndagana (2007) who in his study sees teaching effectiveness and motivation as the opposite sides of the same coin (that is, as twininseparable concepts). To Ndagaha, a well-performing worker is a motivated worker, and vice versa; who is always happy and contented with his work. But the worker feels more contented when he compares in similar organizations and sees no disparity once any disparities are observed the effective worker becomes discontented. These assertions are also corroborated by Ali and Ahmed (2009) who in their study found a statistical significant relationship between reward and recognition, and between motivation and performance; and that, if reward of recognition offered to employees were to be altered, a corresponding charge in work motivation and performance would be observed in a similar vein, the study by Kaya (2005), said that teaching effectiveness plays a great role in the type and quality of service rendered by lecturers, and that appropriate compensation systems must be put in place(s) for motivation of those workers who put their effort for the realization of the ideal objectives of the organization. Such motivational systems have been found to go a long way in boosting the morale of workers to a high extent (Storey \& Sission, 2009). This finding that was also confirmed by Henman (2007) has been adopted by several institutions and proven to be very effective in improving productivity in not only the academic systems, but also in large industries organizational systems, the world over. This is why Gregory (2002) posited that motivation is closely interwoven with behavior, which is influenced by variables such as the needs of individual workers, the attitude of supervisions (or administrators) toward them.

The findings of this study has added credence to the work of Human Psychologists-Ferzberg, Mausner and Synderman, who in the 1959's studied behavior of factory workers and found significant relationships between intrinsic, motivational or growth-oriented factors as extrinsic (maintenance of hygiene) factors of workers with level of organizational productivity. Here, Herzberg and his associates in 1959 found out that human motivation factors of: sense of achievement, recognition for job well done, work itself, responsibility, advancement (promotion opportunities) and actual growth (which is opportunity for capacity building) etc. are all capable of enhancing good teaching effectiveness of teachers. This is because these factors are related to the job content in a similar vein, human maintenance of hygiene factors of institutional (company) policy and administration, 
supervision, working condition; working conditions interpersonal relationships (with peers and superiors), salary and job security. For as asserted by Denga (2006) positive motivation of workers could take the form of prompt payment of their salary is good or poor in a similar manner as a good salary paid lately or irregularly could constitute negative motivation that can affect lecturers' effectiveness adversely. In summary, this study also aligns very well with Etuk (2001) who recommended that certain lecturers in the tertiary institutions, who are assigned special functional duties in addition to their normal teaching functions due to their proven integrity, should be appropriately motivated. This will create in such lecturers a high sense of fulfillment and satisfaction.

\section{Conclusion}

Based on the findings of study, the following conclusions were drawn: That there was significant influence of institutional variables of financial supervision and motivation on the teaching effectiveness of Agricultural Education lecturers' teaching effectiveness in Nigeria universities in terms of classroom design technique, teaching to appropriate behavior, and students-teacher relationship, but not with respect to the teachers self-control. There was significant difference in the teaching effectiveness of Agricultural Education lecturers who institutionally are motivated and those who not motivated only with respect to self-control, teaching of appropriate behavior and students-teacher relationship, but not in term of classroom design technique. The teaching effectiveness of Agricultural Education lecturers' in Nigeria universities was significantly high with respect to all the self-control, classroom design technique, teaching of appropriate behavior, and students-teacher relationship, respectively. The combined effect of institutional variable of financial management supervision and staff motivation are significant predictors of Agricultural Education lecturers' teaching effectiveness in Nigeria Universities.

\section{Recommendations}

On the basis of the findings and conclusion arising there from, the following recommendations were made:

1. The government of Nigeria should increase funding to universities in general and the Agricultural Education Department in particular.

2. Agricultural Education lecturers should be adequately motivated with respect to good offices, provision of adequate institutional materials, visuals and audiovisuals, and adequate financial reward, sponsorship to and conferences and workshops among others.

3. Agricultural education lecturers should be given opportunity to develop their professional capacities. Such opportunities should include in -service courses for higher degree programmes to serve as a source of motivation.

\section{References}

[1] Abi, E. (2007). The influence of school finance on administrative efficiency of secondary schools in Ikom and Obubra Local Government Area (LGA) of Cross River State, Nigeria. Unpublished M.Ed. Thesis, University of Calabar, Nigeria

[2] Afe, J. O. (2003). Reflections on becoming a teacher and the challenges of teacher education. University of Benin Inaugural lecture, Series 64

[3] Aguokoaguo, O. N. (2003). Educational administration and resources management for effective instruction in Nigeria tertiary institution. Journal of WCCI, 4(1), 247-254

[4] Akpama, M. A. (2003). Secondary school resources management effectiveness of teachers' teaching effectiveness in Cross River State. Unpublished Ph.D Dissertation. University of Calabar, Nigeria

[5] Akpama, M. A. (2003). Secondary school resources management effectiveness of teachers' teaching effectiveness in Cross River State. Unpublished Ph.D Dissertation. University of Calabar, Nigeria

[6] Akpan, J. R. (2002). Financial management and administrative efficiency of secondary schools in Akwa Ibom State. Unpublished M.Ed Thesis. University of Calabar, Nigeria

[7] Akubue, A. (2003, October). The key to effective management A look at the over looked (lead paper). The Journal of WCCI 4 (1) , 24-45

[8] Amadi, A. (2002). Effect of principals' leadership behavior on teachers' level of commitment, cooperation and participation in school organization. Unpublished M.Ed Thesis.University of Calabar, Nigeria

[9] Amadi, V. L. (2003). Teacher's perspective on resource management in secondary schools. The Journal of WCCI. 4(2), $91-96$

[10] Ben, C. B. (2014). Quality assurance for effective agricultural teacher preparation and school administration in Nigeria. Proceedings of INTCESS14- International Conference on Education and Social Sciences Proceedings.3-5 February 2014- Istanbul, Turkey,1706 -1712

[11] Bryson, J. (1990). Effective lecturer and knowledge. Aldershot: Gower

[12] Cooper, C. C. \& Rayne, R. (1980). Stress at work: organizational behavior. New Delhi: McGraw-Hill publishing company

[13] Denga, D. I. (2006). An introduction to foundations of education, Calabar: Advanced Publishers and printing consultancy Associates

[14] Denga, D. I. (2003). Education at a glance: from cradle to tomb. Calabar :Rapid Educational publishers

[15] Denga, D. I. (2006). The eve of the $21^{\text {st }}$ century educational threshold strategies for entry and sustainable development.Calabar: Rapid Educational publishers

[16] Edem, D. A. (2002). Introduction to educational administration in Nigeria. Ibadan: Spectrum Books 
[17] Effiong, A. O. (2009). Principals' supervisory techniques and teachers' teaching effectiveness Secondary schools in Southern Senatorial District of Cross River State. Unpublished M.Ed Thesis, University of Calaba, Nigeria

[18] Ekoh, S. J. (2001). Principals' administrative behavior and job satisfaction of teachers in Akwa Ibom State. Unpublished M.Ed Thesis. University of Calabar. Nigeria

[19] Ekpiken, W. E. (2002). Motivation and teachers' perception of principals'administrative effectiveness in Odukpani L. G. A. of Cross River State. Unpublised M.Ed Thesis. University of Calabar, Nigeria

[20] Emosarve, M. E. (2002). Administrative factors and management of higher education in Abia State, Nigeria. Unpublished M.EdThesis. University of Calabar, Calabar

[21] Engeiking, J. L. (1986). Teacher job satisfaction and dissatisfaction. ETS spectrum. 4 (1), 33-38

[22] Etor, R. B. (2002). Herzberg's two factor theory and secondary school teachers' morale in Akwa Ibom State. Unpublished Ph.D Dissertation. University of Calabar, Nigeria

[23] Etuk, E. J. (1991). Foundation of modern business management. Calabar: Unical Press

[24] Ezegbe, B. N. (2003). Improvisation of instructional materials for effective teaching of Agricultural Education in post primary schools. The Journal of WCCI 4(2) 42-51

[25] Ezeocha, P. A. (2005). School management and supervision. Owerri: New African Publishing Company

[26] Fafunwa, A. B. (2004). History of Education in Nigeria. London: George Aken and Unwin

[27] Federal Government of Nigeria (2004). National policy on education. Lagos: Government Press

[28] Frase, L. E, Hetzel, R. W. \& Grant, R. T. (1982). Promoting institutional excellence through a teacher reward system: Herzbery theory applied. Planning and changing teacher reward. 13(2), 67-76

[29] George, J. M. \& Jones, G. R. (2009). Understanding and managing organizational behaviour. $\left(2^{\text {nd }}\right.$ Ed). New York: Addison Wesley company

[30] Gregory, S. U. (2002). The application of Douglas McGregor's theory inadministration of secondary schools in Enugu State, Nigeria. Unpublished M.Ed Thesis University of Calabar, Nigeria

[31] Haruna, I. (2004). Motivational factors as correlates of employee performance in Ramat Library, University of Maiduguri. Annals of Borno 19/20: 89-96

[32] Henman, I. (2005). Staff motivation the key to a strong work environment. Accessed from $\mathrm{h} t t p: / / w w w . t h e f r e e t e a c h e r . c o m o n$ June $4^{\text {th }}, 2014$

[33] Inyang-Abia, M. E. (2004). Essentials of educational technology: A handbook for educators and media practitioners Calabar: Wusen press

[34] John, M. E. (2006). Applicability of Maslow's needs theory among teachers in Cross River State. Unpublished Ph.D Dissertation, University of Calabar

[35] Karmel, E. A. (2001). What is job satisfaction? Organization Behavior and Human Performance 4,309-336
[36] Kaya, E. (2005). Job satisfaction of the librarians in developing countries. $61^{\text {st }}$ IFLA General Conference Conference Proceeding - August 20-25. Accessed from http://www.ifla.org on February 2014

[37] Lodie, M. (2003). University of Science "CRECO" University Centre for evaluation and control. Higher education nowhere to hide from the wings of change. A review of literature on University coping with their environment. Working paper 5

[38] National Universities Commission (NUC). (2006). NUC Brochure (6 ${ }^{\text {th }}$ edition). Abuja: NUC

[39] Ndagana, J. M. (2007). Behavioural pattern of non-academic staff of Federal colleges of education in Nigeria to job dissatisfaction. Educational Forum, 145-150

[40] Nsor, E. (2002). Organisational climate and teacher's professional commitment to duty in secondary schools in Cross River State. Unpublished M. Ed. thesis. University of Calabar

[41] Nyong, G. E. (1991). Factors that influence administrative effectiveness of principals of secondary schools in Akwa Ibom State. Unpublished M.Ed Thesis. University of Calabar

[42] Offiong, A. E. (2004). Correlates of administrative efficiency among secondary school principals in Cross River State. Unpublished M.Ed Thesis. University of Calabar, Calabar, Nigeria

[43] Okedara, J. T. (1991). Preliminary study of secondary school resource management in Lagos state, Nigeria. Unpublished B.Ed project. University of Lagos, Nigeria

[44] Okorie, A. N. (2001). Towards effective fiscal resources management system in the Nigerian Secondary schools: Some guidelines. In N. A. Nwagwu, E. T. Ehiametalor, M. A. Ogunu, \& M. Nwadiahi (Eds). Current issues in educational management in Nigeria. 121-128

[45] Okure, S. J. (2001). Quantitative techniques in educational planning for economic development. Owerri: Executive publishers

[46] Olaloko, A. A. (2001). School plant maintenance practice. Unpublished B. Ed. Project. University of Calabar, Nigeria

[47] Owusu-Acheaw, M. (2007). Staff development and employee welfare practices and their effect on productivity in three special libraries in Ghana. Ghana Library Journal , 19(1), 8389

[48] Robbins, S. P. (2004). Organizational behavior. Concepts, controversies, applications ( $\left.4^{\text {th }} \mathrm{ed}\right)$. New Delhi: Prentice-Hall of India

[49] Siggins, J. A. (2002). Satisfaction and performance in a changing environment. The Trends (41), 304

[50] Sinha, J. (2008). Streamlining processes to achieve organisatonal goals. Accssed from http://www.buzle.com on October 23, 2014

[51] Storey, M. \&Sission, B. (2009) Writing the journal article. Research Libraries 37,(1) 42 -53

[52] Taiwo, B. M. (2006). Maintenance of school infrastructure for productivity in education and productivity in Nigeria. In E. O. Fagbamiye \& D. O. Durosaro (Eds.)lorin: NAEAP. 140-147

[53] Tietjen, M. A. \& Myers, R. M. (1998). Motivation and job satisfaction. Management Decision 36(4), 226-231 